\begin{tabular}{c} 
Volume and Issues Obtainable at Center for Sustainability Research and Consultancy \\
Responsible Education, Learning and Teaching in Emerging Economies \\
ISSN: 2708-4310 (E): 2708-4183 \\
Volume 1: No. 2, December 2019 \\
CSRᄃ \\
Journal homepage: www.publishing.globalcsrc.org/relate \\
\hline
\end{tabular}

\title{
Inclusive Education Facilities in Secondary Schools of Pakistan: A Gender Based Comparison ${ }^{1}$ Muhammad Jahanzaib, ${ }^{2}$ Ghulam Fatima, ${ }^{3}$ Dur e Nayab
}

${ }^{1}$ Phd Scholar, Department of Special Education, University of the Punjab, Lahore, Pakistan

${ }^{2}$ Associate Professor, Institute of Education and Research, University of the Punjab, Lahore: fatima.ier@pu.edu.pk

${ }^{3}$ Phd Scholar, Institute of Education and Research, University of the Punjab, Lahore: durenayab18@yahoo.com

\begin{tabular}{l} 
ARTICLE DETAILS \\
\hline History \\
Revised format: November 2019 \\
Available Online: December 2019 \\
Keywords \\
Inclusive education, facilities, \\
gender, comparison
\end{tabular}

JEL Classification: P36, I21

\section{ABSTRACT}

Man is the most civilized and enlightened creation of Allah. Man and women formulate the basic unit of civilization. A comparison about provision of rights and facilities in every field of life has been going on since their creation. Nowadays inclusive education has proved a successful educational system for persons with disabilities. In this study, researchers have tried to explore difference between inclusive education facilities in male and female secondary schools of the province of Punjab, Pakistan. In order to attain this goal the survey technique was used to collect the data from 196 male and female secondary school teachers working in rural and urban secondary schools conveniently selected from five districts viz Okara, Sahiwal, Lahore, Pakpattan and Kasur by a self developed and validated questionnaire i.e. Research Questionnaire about the Condition of Available Inclusive Education Facilities and Opportunities in Secondary Schools of Punjab. For cross validation of data, interview schedule was used to collect data from 17 secondary school students with disabilities. Both the descriptive and inferential statistics were used to analyze the collected data. This study describes that there is no significant difference in inclusive education facilities between male and female secondary schools. Moreover special students denied provision of inclusive education facilities as claimed by the teachers. Conclusions were drawn and recommendations were made.

(C) 2019 The authors, under a Creative Commons Attribution-

NonCommercial 4.0

Corresponding author's email address: fatima.ier@pu.edu.pk

Recommended citation: Jahanzaib, M., Fatima, G. \& Nayab, D. E., (2019). Inclusive Education Facilities in Secondary Schools of Pakistan: A Gender Based Comparison. Responsible Education, Learning and Teaching in Emerging Economies, 1(2), 75-83

DOI: $10.26710 /$ relate.v1i2.1172

\section{Introduction}

In this tremendous world, human being is the most important creation of Allah. Every person is unique due to his/her personality traits. Different kinds of comparison have been going on between male and female since evolution of civilization. Usually society determines worth of a person by his/her abilities and skills. Therefore some individuals who cannot perform activities of life like common people of 
society are called as persons with disabilities. In different eras, persons with disabilities are being treated by their societies in different ways. Sometimes they were considered as punishment of their parents' sins. So they were cursed and sometimes killed by their families. The condition of female disabled children was particularly miserable.

With the passage of time, people became aware of their rights. In early $19^{\text {th }}$ century, different educational institutions were developed for children with various disabilities in several parts of the world. Segregated and special education module was initially developed in Germany in 1863. In 1894, special education classes emerged in Rhode Island with Boston, Chicago, and Philadelphia (Withers, 2012). Special education is a conventional schooling system for the education of both male and female children with special needs which they are educated in special education centers far from main stream of society. It is a common observation that special education is proved as less beneficial educational system for these children due to its segregated characteristic.

Inclusive education is another emerging approach for educational rehabilitation for children having impairments which students with disabilities get education with their non disabled peers under the same roof of general education school. Many researchers prove that inclusive education is more fruitful for educational rehabilitation of persons with disabilities than segregation. Zollers, Ramathan, and YU (1999) narrate that integration and mainstreaming are outdated, ineffectual special educational arrangements that had structural dearth. (Zollers, Ramathan, \& YU, 1999). In fact, without proper inclusive education facilities, the effective inclusion is just a dream. In this article, researchers would like to elaborate the situation of prevailing inclusive education facilities in Pakistani secondary schools. As well as to compare the situation regarding inclusive education facilities in male and female secondary schools.

\section{Review of Related Literature}

In different eras special children have been treated in different ways by families and society. In the ancient times special children were the most deprived segment of societies. Furthermore, parents had authority to kill their disabled children (Trembley, 2007). Rymer (2014) reports that if a child was born having some abnormality, most of the time he/she might have been left alone on some rocks. Baby girls were left mostly than boys. The result of all above concepts was the exclusion of disabled persons from the communal, financial, political as well as religious sectors of social life (Otieno, 2009). In that time nobody ever thought about the education of person with disabilities. After sometimes, a positive change occurred, when the Catholic Church acknowledged disable people as part of the state. (Tremblay, 2007). In this regard different people started to think about their rights in different ways. Many researcher put varius openions about the start of special education. Jordan wagner narrates that Pedro Ponce de Leon (1578) in Spain formed the first institution about instruction of hearing impaired students. As well as louise Braille invented Braille system for blind people in 1829. (Wagner, 2011)Winzer states that Maria Montessori, the first lady in Italy to obtain a medical degree, became famous not only as an instructor of mentally challenged learners, but also as an campaigner of early tutoring for children with disabilities. (Winzer, 1993). On the other hand Hallahan and Kauffman writes a myth about special education as it started in America. (Hallahan \& kauffman, 1988). Segregated and special education" module first started in Germany in 1863. (Withers, 2012). In 1975 American congress passed an act about the education for all disabled students (94-142) in community Law named "The Education for All Handicapped Children Act". This act advises that all learners with disabilities receive a free, suitable public education and provided a financial support. Later this act became famous as IDEA. (Martin, Martin, \& Terman, 1996). Meanwhile some new terms were evolved like integration and mainstreaming for the educational rehabilitation of PWDS. Mason defines integration as customarily refers to the teaching of disabled students in general educational institutions" (Mason, 2002).Although various approaches like integration, mainstreaming, and inclusive education played a significant role in educational rehabilitation of PWDS but on the other side some barriers still restrict the equal chances for special people. One of those barriers 
is gender based inequality. Many researches prove that the educational facilities/opportunities are not same even for the non-disabled males and females. A report tells that above 75 countries have not achieved the 2005 MDG targets for gender equality at primary \& secondary level. There were 23 million girls far from educational institutions in sub-Saharan Africa. Moreover 22 million out-of-school female children were present in different parts of Asia. The majority of these girls are living in just two countries Pakistan and India. (DFID, 2005) Most of the girls who have some education cannot take benefits from it. A study describes that in fact education shows a significant role in search of occupation for males from initial classes of education. On the other hand women begin to take financial benefits from their education at least from matriculation level. (Tembon \& Fort, 2008). Palmer Woodcoft-Lee narrate that Disabled females bear specially drawbacks in education, work and job seeking etc. There is a severe shortage of sufficient handicapped women at significantly prestigious status. (Palmer \& Woodcoft-Lee, 1990). In spite of various policies for health, education and rehabilitation devised by many countries of south Asia, females with disabilities have less access to facilities. (Thomas \& Thomas, 2002). First time Salamanca statement emphasized on inclusive schooling for every kind of children bluntly. (UNO, 1994).

British Psychological Society (2002) states that inclusion is concerning the students' right to contribute completely in the activities of educational institution and the responsibility to receive and accept special children with open arms. (Booth \& Ainscow, 2002) New Brunswick Canada is obligatory to make available Inclusive Education. (Peters, 2003). In Germany handicapped people are granted assistive devices and adjustments to enhance independence and ease of access in their routine life. (Waldschmidt \& Meinert, 2010)

On the other side in spite of states, NGOs, different cooperation of United Nation and others have taken steps to fulfill the special learning needs of handicapped kids in an integrated school atmosphere in different states of South Asia, they could make only a partial impact. (UNICEF,2005) For example A source of Abhiyan elaborates the situation of the division of aids and equipments which provided disabled students by Government in India, year wise with this table: Distribution of aids and appliances

Table 2.3

Distribution of aids and appliances

\begin{tabular}{ll}
\hline Year & Distribution of aids and appliances to CWSN \\
\hline $2003-4$ & 121,467 \\
$2004-5$ & 286,922 \\
$2005-6$ & 370,397 \\
$2006-7$ & 711,971 \\
$2007-8$ & 832,828 \\
\hline
\end{tabular}

Source: Abhiyan (2007)

In Pakistan national policy for persons with disabilities 2002 was important step towards the inclusive education. The mission statement of above mentioned policy describes: best possible development of special people for the recognition of their total capacity in every field of life, particularly in education sector. (Education G. o., 2002).

\section{Scope and Purpose of Study}

Persons with disabilities have been considering as a marginalized segment of society since start of civilization. Many approaches were introduced for their education in different eras. Inclusive education is an emerging ideology for the educational rehabilitation of PWDS which proved as an effective approach. Nowadays the majority of educational experts prefer inclusive education for disabled children in whole world, and Pakistan is also taking interest in it. Infact inclusion is a fruitful approach but without some essential arrangements and facilities the goal of successful inclusion cannot be attained. Gender 
discrimination is a great issue of civilized world. This issue becomes more serious in case of disability. The purpose of this study is to identify and to compare the prevailing inclusive education facilities in male and female secondary schools of Punjab Pakistan.

\section{Research Questions}

1. What is the existing situation of inclusive education facilities in secondary schools of Pakistan?

2. Is there any difference in prevailing inclusive education facilities between male and female secondary schools?

\section{Methodology}

The present study was conducted to identify as well as to compare the prevailing inclusive education facilities in male and female secondary schools of Punjab Pakistan. The study at hand is descriptive research by nature. According to Creswell surveys grant worthwhile data to appraise programs and facilities in educational institutions (Creswell, 2012). Due to such type of experts' opinion, survey technique was used to collect the data from research participants.

\section{Sampling Technique}

In order to assure comprehensive representation of population, the convenient sampling technique was used to select the sample of the study. For the selection of sample collection five districts viz Okara, Sahiwal, Lahore, Pakpattan and Kasur were conveniently selected. The convenient sampling technique was use because of the visual impairment of the researcher as he could not collect data from far off districts of the Punjab. From all the five districts the researcher randomly selected 20 schools including 10 rural and 10 urban schools. The rural and urban schools were further divided into two strata i.e. 5 male schools and 5 females.

From the selected 100 schools secondary level teachers were again randomly selected for the data collection. Thus the sample of this study comprised of 300 teachers questionnaires were delivered to all the 300 teachers and 196 teachers returned the filled questionnaires.

\section{Instrumentation}

The $1^{\text {st }}$ instrument was a self-reporting questionnaire for secondary school teachers i.e. Research Questionnaire about the Condition of Available Inclusive Education Facilities in Secondary Schools of Punjab. This questionnaire consists on18 items about inclusive education facilities. The co-efficient of reliability (Cronbach Alpha) was calculated for the scale and it turned out as .882.

The $2^{\text {nd }}$ instrument was an interviews schedule for the disabled students studying at secondary level in inclusive education. There were 17 items in the interview schedule as it was of structured type. For the convenience of the students the interviews were conducted in Urdu and later on transcribed in English for further analysis.

\section{Data Collection}

For the purpose of data collection from the teachers the questionnaires were personally administered to the teachers of selected schools. From some schools which situated in far-flung areas data was collected with the help of researcher's friends, class fellows and colloquies. The $2^{\text {nd }}$ phase of data collection was interviews of disabled students studying in inclusive education. These interviews were personally conducted by the researcher.

\section{Data Analysis}

Both the descriptive and inferential statistics were used to analyze the collected data. The decision about the facilities for inclusive education was taken on the basis of mean score of the mean of the respondents. 
Whereas, the differences of facilities in the male and female schools were determined through the application of t-test. The interviews were transcribed, coded, and decoded to determine the frequency of coded aspects.

\section{Findings and Results}

\section{Table 1}

Teachers' opinions about the presence of slopes and ramps

\begin{tabular}{clccc}
\hline Statement & Responses & Frequency & Percentage & $\begin{array}{c}\text { Mean } \\
\text { Score }\end{array}$ \\
\hline Slopes/ Ramps & Not Available & 146 & 74.9 & \\
& Poor & 22 & 11.3 & \\
& Satisfactory & 21 & 10.8 & 1.43 \\
& Good & 5 & 2.6 & \\
& Excellent & 1 & .5 & \\
\hline
\end{tabular}

The $t$ above table reflects that most of the respondents $(74.9 \%)$ stated that in their institution slopes and ramps are not available for the disable students. The mean score ( $\bar{X}=1.43)$ also describes the unavailability of the said facility.

\section{Table 2}

Teachers' opinion about presence of accessible washroom for handicapped persons

\begin{tabular}{llccc}
\multicolumn{1}{c}{ Statement } & Responses & Frequency & Percentage & $\begin{array}{c}\text { Mean } \\
\text { Score }\end{array}$ \\
\hline Accessible & Not Available & 144 & 73.8 & \\
washrooms for & Poor & 24 & 12.3 & \\
handicapped persons & Satisfactory & 12 & 6.2 & 1.49 \\
& Good & 12 & 6.2 & \\
& Excellent & 3 & 1.5 & \\
\hline
\end{tabular}

The above table shows that the large no of respondents $73.8 \%$ tells that there is no accessible washrooms facility for handicapped students available in their institution. The mean score $(\bar{X}=1.49)$ also represents the absence of above mention facility.

\section{Table 3}

Teachers' opinions about the presence of accessible library

\begin{tabular}{clccc}
\hline Statement & Responses & Frequency & Percentage & $\begin{array}{c}\text { Mean } \\
\text { Score }\end{array}$ \\
\hline Accessible library & Not Available & 102 & 52.3 & \\
& Poor & 32 & 16.4 & \\
& Satisfactory & 31 & 15.9 & 1.99 \\
& Good & 21 & 10.8 & \\
& Excellent & 9 & 4.6 & \\
\hline
\end{tabular}

The table above narrates that the big no of respondents $52.3 \%$ says there is no accessible library for every student in their schools. The mean score $(\bar{X}=1.99)$ also describes the shortage of this facility. 


\section{Table 4}

Teachers' opinions about the sufficient lighting arrangement in classrooms

\begin{tabular}{llccc}
\hline \multicolumn{1}{c}{ Statement } & Responses & Frequency & Percentage & $\begin{array}{c}\text { Mean } \\
\text { Score }\end{array}$ \\
\hline Well illuminated & Not Available & 98 & 50.3 & \\
classrooms & Poor & 24 & 20.3 & \\
& Satisfactory & 39 & 12.0 & 2.09 \\
& Good & 26 & 13.3 & \\
& Excellent & 8 & 4.1 & \\
\hline
\end{tabular}

The table above expresses that almost the half no of the respondents $50.3 \%$ denied the presence of well illuminated classrooms in their educational institutions. The mean score $(\bar{X}=2.09)$ too mentions this reality.

\section{Table 5}

Teachers' opinions about the presence of plane and obstacle free walkways

\begin{tabular}{llccc}
\hline Statement & Responses & Frequency & Percentage & $\begin{array}{c}\text { Mean } \\
\text { Score }\end{array}$ \\
\hline Plane and obstacle & Not Available & 118 & 60.5 & \\
free Walkways & Poor & 35 & 17.9 & \\
& Satisfactory & 23 & 11.8 & 1.72 \\
& Good & 17 & 8.7 & \\
& Excellent & 2 & 1.0 & \\
\hline
\end{tabular}

The table above describes that a large no of respondents $60.5 \%$ tells that the walkways of their schools are not plane and obstacle free. The mean score $(\bar{X}=1.72)$ is also elaborates this reality.

Table 6

Teachers' opinions about the feasible arrangement of classroom chairs for students with special needs

\begin{tabular}{llccc} 
Statement & Responses & Frequency & Percentage & $\begin{array}{c}\text { Mean } \\
\text { Score }\end{array}$ \\
\hline ible arrangement & Not Available & 136 & 69.7 & \\
lassroom chairs for & Poor & 26 & 13.3 & \\
ents with special & Satisfactory & 16 & 8.2 & 1.58 \\
& Good & 12 & 6.2 & \\
& Excellent & 5 & 2.6 & \\
\hline
\end{tabular}

The table above shows that the most of the respondents tells that the arrangement of classroom chairs is usually not feasible for students with disabilities. The mean score $(\bar{X}=1.58)$ is also describes the lack of above mention facility.

\section{Table 7}

Teachers' opinions about the accessible computer lab

\begin{tabular}{clccc}
\hline Statement & Responses & Frequency & Percentage & Mean Score \\
\hline Accessible computer lab & Not Available & 92 & 47.2 & \\
& Poor & 32 & 16.4 & \\
& Satisfactory & 23 & 11.8 & 2.23 \\
& Good & 31 & 15.9 & \\
& Excellent & 17 & 8.7 & \\
\hline
\end{tabular}


The table above shows that a big no of respondents $47.2 \%$ says that accessible computer lab for everyone does not exist in their schools. The mean score $(\bar{X}=2.23)$ also tells about the unavailability of accessible computer lab.

\section{Table 4.4.1}

\section{Analysis of Special Students Interview}

\section{Special students' opinions about prevailing inclusive education facilities}

\begin{tabular}{|c|c|c|c|c|c|c|c|c|c|}
\hline \multirow{3}{*}{$\begin{array}{l}\text { Item } \\
\text { No } \\
\\
1\end{array}$} & \multirow{3}{*}{$\begin{array}{l}\text { Statements } \\
\text { Facilities } \\
\begin{array}{l}\text { Whether you can go easily at all the parts of the school where non disabled } \\
\text { students can go easily? }\end{array}\end{array}$} & \multicolumn{8}{|c|}{ Responses } \\
\hline & & \multicolumn{2}{|c|}{ Yes } & \multicolumn{2}{|c|}{ No } & \multicolumn{2}{|c|}{ To some extent } & \multicolumn{2}{|c|}{$\begin{array}{c}\text { Not } \\
\text { Applicable }\end{array}$} \\
\hline & & 9 & $\begin{array}{l}52 . \\
9 \%\end{array}$ & 7 & $\begin{array}{l}41 \% \\
1 \%\end{array}$ & & & & \\
\hline 2 & $\begin{array}{l}\text { Are the facilities like, Library, computer lab, play ground, and washrooms } \\
\text { fulfill your special needs? }\end{array}$ & 7 & $\begin{array}{l}41 \% \\
1 \%\end{array}$ & 10 & $\begin{array}{l}58 . \\
8 \%\end{array}$ & & & & \\
\hline 3 & Do the arrangements of classroom chairs create trouble for you? & 4 & 23. & 9 & $\begin{array}{l}52 . \\
9 \%\end{array}$ & 4 & $\begin{array}{l}23 . \\
5 \%\end{array}$ & & \\
\hline 4 & $\begin{array}{l}\text { Whether school is providing you appropriate equipments to cope with your } \\
\text { disability related problems? }\end{array}$ & 1 & $\begin{array}{l}5.8 \\
8 \%\end{array}$ & 9 & $\begin{array}{l}52 . \\
9 \%\end{array}$ & & & 7 & $\begin{array}{l}41.1 \\
\%\end{array}$ \\
\hline 5 & Did you get any kind of scholarship from the school? & 4 & 23. & 13 & $\begin{array}{l}76 . \\
4 \%\end{array}$ & & & & \\
\hline 6 & $\begin{array}{l}\text { How much are you satisfied from instructional and examination methodology } \\
\text { of school? }\end{array}$ & $\begin{array}{l}\text { Fully } \\
\text { satisfied } 5\end{array}$ & 29. & $\begin{array}{l}\text { Satisfie } \\
\text { d } 10\end{array}$ & $\begin{array}{l}58 . \\
8 \%\end{array}$ & $\begin{array}{l}\text { Dissatisf } \\
\text { ied }\end{array}$ & 2 & 11. & \\
\hline 7 & $\begin{array}{l}\text { Does school provides you the facility of Braille writing, helping writer and } \\
\text { extra time in exams? }\end{array}$ & 4 & 23. & 2 & 11. & $\begin{array}{l}\text { Sometim } \\
\text { es } 2\end{array}$ & $\begin{array}{l}11 \% \\
7 \%\end{array}$ & 9 & $\begin{array}{l}52.9 \\
4 \%\end{array}$ \\
\hline
\end{tabular}

\section{Discussion}

The present study aimed at identifying the prevailing inclusive education facilities in the secondary schools of Punjab Pakistan. Similarly the comparison of existing inclusive education facilities in male and female secondary schools is also purpose of the study. The study depicts that there is a severe lack of inclusive education facilities in the secondary schools of Punjab. It is an important finding as it supports most of the researches about the existing condition of inclusive education facilities in south Asian schools. The study conducted by United Nations Children Fund titled "Examples of Inclusive Education Pakistan" narrates that in fact, there is no comprehensive effort made for the provision of inclusive education in Pakistan. (UNICEF, examples of inclusive education pakistan, 2003). Moreover Malik and Fatima (2013) endorse the present study in their research paper about Physical and Professional Facilities for Students with Special Needs in Government Special Education Centers in Punjab, Pakistan in this way just 4 special education schools out of 19 (21\%) had their personal buildings. . (Malik \& Fatima, 2013). On the other hand Julka and Bansal (2013) contradict the present study in the way that there are many high quality centrally sponsored programmes like the IEDSS which offers hundred percent provision to make easy inclusive education at secondary and higher secondary stage, . (Julka \& Bansal, 2013). 


\section{Conclusions}

1. There is a lack of inclusive education facilities and supportive devices like, accessible library , accessible computer lab, special need base softwares for special students, audio recording equipments, necessary Braille equipments, Braille books, talking calculators, hearing aids and magnifying devices in the secondary schools of Punjab.

2. Most of the secondary schools of Punjab province have not least restrictive environment for the free and independent mobility of persons with disabilities because these schools have not plane obstacle free walkways, slopes and ramps, pick and drop service for special students, accessible washrooms for handicapped persons, wheel chairs as well as crutches and braces.

3. Most of the secondary schools of Punjab province have not good classroom environment for inclusive education due to lack of well illuminated classrooms, microphone facility and feasible arrangement of classrooms chairs for students with special needs.

4. The present study describes that there is no significant difference in inclusive education facilities between male and female secondary schools.

The conclusion extracted from interviews of special students is as under:

The secondary schools of Punjab do not have accessible libraries, computer labs, play grounds, washrooms, and appropriate equipments to cope with their disability related problems. It is because majority of special students believed that special education school is better than their general education school.

\section{References}

Booth, T., \& Ainscow, M. (2002). Index for inclusion developing learning and participation in schools. Educational psychology in practice, 102.

Creswell, J. W. (2012). Educational Research Planning, Conducting, and Evaluating Quantitative and Qualitative Research. Boston: Pearson Education.

DFID. (2005). Girls education towards a better future for all. Department for International Development.

Education, G. o. (2002, november 25). national policy for persons with disabilities. pp. 1-14. Hallahan, D. P., \& kauffman, J. M. (1988). Exceptional children introduction to special education, Fourth edition. New Jersey: 1988 by Prentice Hall a divison of Simon and Sichuster, Englewood Cliffs, New Jersey, 07632.

Julka, A., \& Bansal, I. (2013). Evaluation of the implementation of the scheme IEDSS in India. New Dehli.

Malik, M., \& Fatima, G. (2013). a study of physical and professional services available for students with special needs in government special education centres of punjab province. Lahore.

Martin, E. W., Martin, R., \& Terman, D. L. (1996). The Legislative and Litigation history of special education. The future of children volume no 6, no.1 , 25-39.

Mason, D. H. (2002, april). 3ed workshop on training of teachers of the visually impaired in Europe. Warsaw, Poland: ICEVI.

Otieno, P. A. (2009). Biblical perspectives on disability and emerging theological themes. Disability studies quarterly the first journal in the field of disability studies volume 29 no. 4 .

Palmer, D., \& Woodcoft-Lee, P. (1990). Womenof the shadow Universe:The relationship between gender and disability and its effect on the lives of women with disabilities. canberra: australian public affairs information service.

Peters, S. J. (2003). Inclusive Education: Achieving Education for All by including those with. USA.

Rymer, E. (2014). Children of ancient greece. Retrieved 11 16, 2014, from Make your words echo into the future. 
Tembon, M., \& Fort, L. (2008). Girls Education in the 21st Century Gender Equality,Empoerment,and Economic Growth. The World Bank.

Thomas, M., \& Thomas, M. (2002). Status of women with disabilities in South Asia.

Asia pacific disability rehabilitation journal/disability, $C B R$ and development .

UNICEF. (2003). examples of inclusive education pakistan. kathmandu: UNICEF.

Wagner, J. (2011, april 25). Retrieved from Prezi.com.

Waldschmidt, A., \& Meinert, S. (2010). ANED country report on equality of educational and training opportunities for young disabled people. ANED.

Withers, A. ( 2012, January 1). Special education is segregation. Retrieved 11 5, 2014, from www.stillmyrevolution.com.

Zollers, N. J., Ramathan, A. K., \& YU, M. (1999). The relationship between school culture and inclusion. International Journal of Qualitative Studies in Education , 157-174. 